ppi $201502 Z U 4645$

Esta publicación científica en formato digital es continuidad de la revista impresa ISSN-Versión Impresa 0798-1406 / ISSN-Versión on line 2542-3185Depósito legal pp $197402 Z$ U34

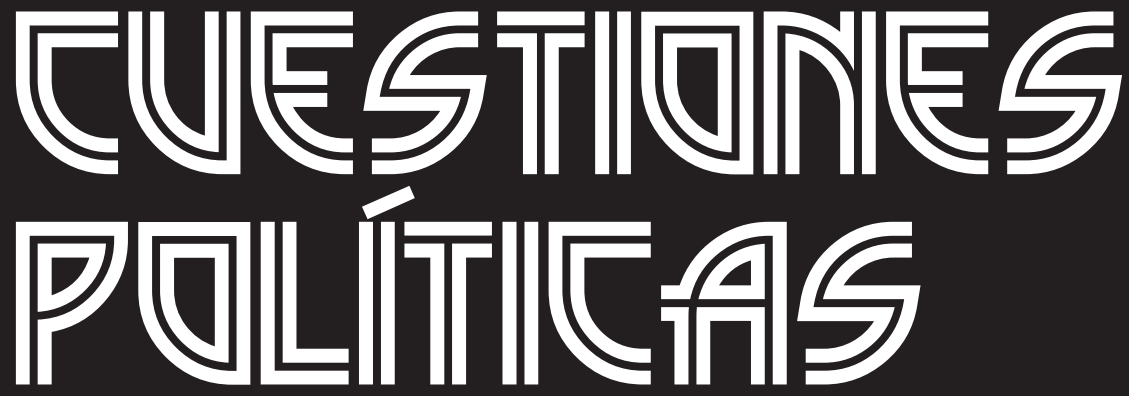

Instituto de Estudios Políticos y Derecho Público "Dr. Humberto J. La Roche" de la Facultad de Ciencias Jurídicas y Políticas de la Universidad del Zulia Maracaibo, Venezuela
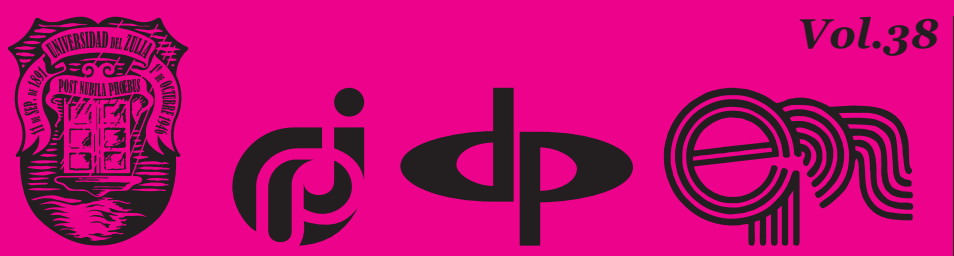

$N^{\circ}$ Especial 1era Parte 2020 


\title{
Media clips on social fear to regulate individual behavior in temporary involuntary isolation (quarantine)
}

\author{
DOI: https://doi.org/10.46398/cuestpol.38e.o4
}

\author{
Tatyana A. Olkhovaya * \\ Elena A. Sorokoumova ** \\ Nikolai A. Mashkin *** \\ Tatyana S. Vinogradova $* * * *$ \\ Jhanna I. Aytuganova ***** \\ Igor V. Romanov ****** \\ Evgeniya V. Gots ******* \\ Irina R. Pozdnyakova $* * * * * * *$
}

\section{Abstract}

The objective of the research was to study the manifestation of the emotion of fear in the context of the COVID-19 pandemic and to determine the details of its application in the clips of social networks. As a research method, the authors used the questionnaire survey to collect primary information. The novelty and originality of the study lies in the fact that the phenomenon of social fear in temporary forced isolation is investigated. For the first time, it is discovered that the overall goal of social

* Doctor of Education, Professor, Vice Rector on Educational Activity, Orenburg State University, Orenburg, Russia. ORCID ID: https://orcid.org/oooo-ooo1-8665-3587. Email: tatjana.olhovaja@ mail.ru

** Doctor of Psychology, Professor of the Department of Labor Psychology and Psychological Counseling, Moscow Pedagogical State University, Moscow, Russia. ORCID ID: https://orcid.org/oooo-0oo22060-7657. Email: cea51@mail.ru

*** Doctor of Historical Sciences, Professor of the Department of State Law and Criminal Law Disciplines, Plekhanov Russian University of Economics, Moscow, Russia. ORCID ID: https://orcid.org/ooooooo3-3643-7530. Email: mashkin.n.a@mail.ru

**** PhD in Law, Associate Professor of the Department of Jurisprudence, Intellectual Property and Forensic Expertise, Bauman Moscow State Technical University, Moscow, Russia. ORCID ID: https:// orcid.org/oooo-0003-1181-4897. Email: vinogradova-bmstu@yandex.ru

*****PhD in Education, Associate Professor of the Department of Foreign Languages, Kazan State Power Engineering, Kazan, Russia. ORCID ID: https://orcid.org/oooo-0003-3505-401X. Email: karinajhanna@mail.ru

*****PhD in Psychology, Dean of the Faculty of Communication Management, Russian State Social University, Moscow, Russia. ORCID ID: https://orcid.org/oooo-0003-1138-4233. Email: ig.v.romanov@gmail.ru

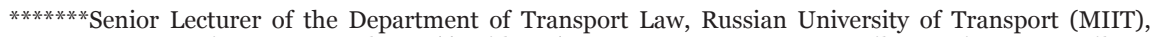
Moscow, Russia. ORCID ID: https://orcid.org/oooo-0o01-7623-6798. Email: evgeniya.goc@mail.ru

*******PhD in Education, Associate Professor of the Department of Psychology and Education, Gzhel State University, Elektroizolyator, Russia. ORCID ID: https://orcid.org/oooo-0002-6214-6553. E-mail: pozdnyakova-ir@art-gzhel.ru

Recibido: 03/03/2020

Aceptado: 08/04/2020. 
Tatyana A. Olkhovaya, Elena A. Sorokoumova, Nikolai A. Mashkin, Tatyana S. Vinogradova, Jhanna I. Aytuganova, Igor V. Romanov, Evgeniya V. Gots y Irina R. Pozdnyakova

media videos affecting the emotion of fear is to create a common problem that forces potential viewers to choose self-isolation. It is concluded that the analysis of the clips from social networks revealed four main directions to position the emotion of fear: fear associated with a direct threat to the life activity of individuals; fear caused by unforeseen situations; fear associated with situations that can be harmful to health; fear associated with nonconformity with certain values and norms accepted in society, with the fear of differing from established standards and benchmarks.

Keywords: social fear; social advertising; Media clips; COVID-19 pandemic; self-isolation.

\section{Clips mediáticos sobre el miedo social para regular el comportamiento individual en el aislamiento involuntario temporal (cuarentena)}

\section{Resumen}

El objetivo de la investigación fue estudiar la manifestación de la emoción del miedo en el contexto de la pandemia del COVID-19 y determinar los detalles de su aplicación en los clips de las redes sociales. Como método de investigación, los autores utilizaron la encuesta por cuestionario para recopilar información primaria. La novedad y originalidad del estudio radica en el hecho de que se investiga el fenómeno del miedo social en el aislamiento forzado temporal. Por primera vez, se descubre que el objetivo general de los videos de medios sociales que afectan la emoción del miedo es crear un problema común que obligue a los potenciales espectadores a elegir el autoaislamiento. Se concluye que el análisis de los clips de las redes sociales reveló cuatro direcciones principales para posicionar la emoción del miedo: el miedo asociado con una amenaza directa a la actividad de la vida de los individuos; miedo causado por situaciones imprevistas; miedo asociado a situaciones que pueden ser perjudiciales para la salud; miedo asociado con la no conformidad con ciertos valores y normas aceptados en la sociedad, con el temor de diferir de los estándares y puntos de referencia establecidos.

Palabras clave: miedo social; publicidad social; Clips mediáticos; pandemia COVID-19; autoaislamiento. 


\section{Introduction}

Emotions are a driving force in a person's daily life. With knowledge of the human psyche, marketers, psychologists, advertisers, and PR specialists began to apply emotions as a strong motivator that can influence consumer behavior. A sense of fear encourages people to adapt to alarming and unpredictable situations, activating processes responsible for selfpreservation and safety (Usak et al., 2020). According to the majority of experts, such negative emotions as fear have a stronger impact on a person than positive ones: they are faster inducing to action and better manage motives (Kanbul et al., 2019). This conclusion determines the interest in the emotions of fear from marketers, advertisers, and PR-specialists. In a number of studies and observations of consumer behavior, experts have found that fear is an excellent manipulator that can be successfully applied in various social campaigns.

Today there is a tendency in science to study in detail the behavior of a person and to analyze emotions, which are considerably transformed in modern societies and cultures. During the last decades, the interest of scientists to study the role of emotions in relation to social actions has been clearly traced. Emotions as typical and normative internal states of actors act as a necessary link between an individual and the social structure (Kostandov, 1977; Putilina et al., 2019; Olkhovaya et al., 2019; Sorokoumova, 2009; Zakharov, 1995; Izard, 1999; Cherdymova, 2017; Melnichuk and Osipova, 2017; Khairullina et al., 2019; Kepalaite and Suvorova, 1991). They support social solidarity while promoting social change.

A person of course, has learned to manage his or her emotions according to social and cultural rules, but not in all life situations, this is possible. Nevertheless, individuals tend to develop ways of managing emotions according to their social context (Sorokoumova et al., 2019; Mishin, 1984; Vasbieva et al., 2018; Gudkov, 1999; Vilyunas, 1976; Ivantsova, 2003; Cherdymova et al., 2019). The research conducted in the field of fear studies can be conventionally divided into three areas, depending on methodological approaches and science schools: social-philosophical, psychological, and sociological. Philosophers were the first to talk about the problem of fear as one of the main features of human nature. It is important to note that virtually all philosophical teachings, currents or schools have addressed fear within their respective worldview systems (Oizerman, 1974; Hegel, 1977; Nietzsche, 1990; Schopenhauer, 1971).

Almost from the beginning of its formation, philosophical thought considers fear as one of the most important phenomena of human and social existence. The theory of fear has found its continuation in psychoanalytic 
Tatyana A. Olkhovaya, Elena A. Sorokoumova, Nikolai A. Mashkin, Tatyana S. Vinogradova,

Jhanna I. Aytuganova, Igor V. Romanov, Evgeniya V. Gots y Irina R. Pozdnyakova 76 Media clips on social fear to regulate individual behavior in temporary involuntary isolation (quarantine)

concepts that explain the phenomenon of fear from the psychological point of view (Freud, 1997; Adler, 1997, Horney, 1982). More developed the problem of fear turned out to be in the well-known philosophicalpsychological direction - existentialism (Heidegger, 1994, Jaspers, 1991). In addition, the main methodological principles of fear and the phenomena associated with it are outlined in the framework of the modern discipline the psychology of emotions (Leontiev, 1984; Wundt, 1913; Ekman, 2010).

In psychology, the concept of emotion has a narrow and broad meaning. In the narrow sense, emotions are defined as a special kind of mental processes expressing a person's experience of his or her attitude to the world around him or herself. In the broad sense, emotions are understood as the complete emotional reaction of a person that includes not only the mental component - experience, but also specific physiological changes in the body that accompany this experience. In this case, it is expedient to speak about the emotional state of a person (Reikovsky, 1979; Rubinstein, 1973; Stevene, 1996; Shingarov, 1971). At present, there are different viewpoints on nature and the meaning of emotions (Vilyunas, 2004; Konopkin, 2006; Dodonov, 1987; Kostandov, 1977).

It should be noted that most social fears are multiple by nature. The basis of catastrophic consciousness is fear of the future. In our opinion, it becomes especially relevant in conditions of temporary forced isolation, which means limitation of personal contacts of an individual or a group of people from other persons, where communication takes place indirectly (by means of telephone, Skype, messages, etc.). As we know, this kind of fear has been rooted in human consciousness and has cultural content since ancient times. Thus, fear acts as a universal alarm indicator in the dynamics of social, cultural, environmental, anthropogenic, economic changes.

\section{Research Objectives and Structure}

The empirical study consists of two stages. In the first stage, the object of the study is social advertising spots on the coronavirus pandemic and self-isolation, which show or talk about the emotions of fear. The study was conducted as part of a qualitative approach using a qualitative data analysis method. In the second phase of our study, the subject is a group of working people aged 24 to 55 years. The study was conducted as part of a qualitative approach using an online forum discussion method. The people who took part in the conversation were selected through a targeted random sample. A group of 13 people was formed.

Thus, at the first stage of the research social advertising spots appealing to the emotions of fear are analyzed. In the second stage, an online discussion 
is held, discussing the social videos on the coronavirus pandemic and selfisolation in a forum format.

The purpose of these two stages was:

To analyze the content of the social clips on the coronavirus pandemic and self-isolation on using the emotion of fear.

To identify subjective perceptions by potential consumers of social advertising that demonstrates fear on coronavirus pandemics and selfisolation.

The questions used in the study:

What is your first impression of the social video you watched?

What did you think when you watched the social video?

What was in social advertising about the coronavirus and self-isolation during pandemic that led you to think about it?

Did you like this social advertising or not?

What exactly you liked in the public service announcement about the Coronavirus Pandemic and self-isolation?

If you did not like this social advertising, then what exactly you did not like in it?

What is your mood after watching such a social advertising video?

What emotions do you get from it: optimism, pessimism, boredom, and any other emotions? Why does this social advertising spot evoke such emotions?

What do you think is the main idea of this social advertising? What do you think this social advertising is created for?

What do you think about the information contained in this social video? Does it inspire your trust or not? If it does not inspire trust, why?

After watching this social video about the coronavirus and self-isolation pandemic, would you do the right thing? What makes you want to do it?

What should be changed in this social video about the Coronavirus and Self-Insulation Pandemic? What should be added or removed? Why do you think so? Questions are asked after each video. 
Tatyana A. Olkhovaya, Elena A. Sorokoumova, Nikolai A. Mashkin, Tatyana S. Vinogradova,

Jhanna I. Aytuganova, Igor V. Romanov, Evgeniya V. Gots y Irina R. Pozdnyakova

Media clips on social fear to regulate individual behavior in temporary involuntary isolation

\section{Research of Perception on Social Clips Related to Self- Isolation and Coronavirus}

Moving to the resolution of the first unit of tasks it is necessary first, to identify, whether the emotions of fear are touch upon in the social advertising dedicated to the coronavirus pandemic and self-isolation; second, to describe the social advertising that contains a component of fear and, third, to try to explain why and how this emotion is used in them.

Then we proceed to the analysis of media social videos, where we find that fear is actively used in social videos related to self-isolation. It should be noted that in many social videos dedicated to self-isolation and coronavirus, the emotion of fear is used as an intimidating component, probably because its producers are aware of the effectiveness of its use. They tell potential viewers the opinion that people staying at home, first, get a guarantee of safety.

Having analyzed social advertising of successful and ordinary people, we did not find any cardinal differences in how they use the emotion of fear. Thus, it can be argued that almost all the analyzed social videos (97\%), dedicated to coronavirus and self-isolation, are aimed at attracting the attention of viewers and use the emotion of fear as a mechanism to regulate behavior. On the basis of the analyzed social advertising materials devoted to self-isolation and coronavirus, it is possible to allocate four basic directions of positioning of fear emotion: the fear, which is connected with direct threat of individual's vital activity (35\%); the fear caused by unforeseen situations (32\%); the fear connected with situations which can cause harm to health (21\%); the fear connected with nonconformity to certain values and the norms accepted in a society, with fear to differ from the set standards and behavioral standards (35\%). It is these fears can be seen when analyzing social advertising spots on self-isolation and coronavirus. Of course, if one continues to analyze social advertising materials in the future, one can expand the classification.

Moving to the second phase of the study, which aims to determine the subjective perception of potential viewers of media social clips on the coronavirus pandemic and self-isolation that demonstrate fear, an online discussion was held in a forum format. Responding to the first task, one should note the various reactions of informants to the video: positive, negative, neutral. "Advertising spots of this format do not attract my attention in any way"; (male, 26 years old) (neutral reaction, in $7 \%$ of cases). "My first impression of this video is good" (female, 25 years old); (positive reaction, in $21 \%$ of cases).

The plot is very scary, very scary" (female, 25 years old) (negative reaction in $72 \%$ of cases). Having analyzed the answers of the participants, 
it was revealed that about half of them liked the social video by its content. "I like everything so saturated and not as usual; it is so special, it attracts attention" (female, 37 years old); and the other half did not like "I did not like it. It's all mixed up. It is about everything and about nothing" (male, 53 years). Participants highlighted such emotions as fear, positive, excitement, optimism, boredom, and neutral attitude. The analysis showed that a large half of the participants (61\%) felt negative emotions "The video causes fear, and it seems to me that it was made a gaffe, in a hurry" (female, 30 years old).

Next, a survey was conducted among participants on how they understood the basic idea of advertising and received such opinions: "The basic idea of this advertising is a healthy lifestyle. Advertising promotes that we need to strengthen ourselves with sports so that we can find a way out of any, even the most terrible situation". (Male, 47 years old); "It is created for us to watch and distract from the problem" (male, 30 years old). More than half of the participants would not like to see this social video on TV or on the Internet: "no, one should not show it better, it scares me (female, 39 years old); "Yes, it is better to remove it, protect our brains and nerves" (male, 30 years old). The rest believe that social videos need to be corrected and modified (13\%), "one cannot show the problem so clearly that one do not make the audience to be negative" (female, 30 years old). Almost all participants in the discussion concluded that in these media social videos dedicated to the coronavirus pandemic and self-isolation, nothing needs to be changed, added or removed (87\%) "Nothing needs to be changed, everything is very good in these videos" (male, 44 years old) "very positive.

This is the main thing. There are so many problems in life" (female, 27 years old). In addition, people's opinions were distributed in this way: the majority of people believe that such social videos should be broadcast at a minimum (1\%) "it is not good idea to show them" (female, 35 years old), and the rest of the participants believe that the plot of social videos dedicated to the coronavirus pandemic and self - isolation should be made more soft (99\%) "Well, if one radically changes the plot, makes it not so acute-the coronavirus and the victims, and adds some optimism" (male, 48 years old).

If we talk about the informants' emotions that caused social videos about the coronavirus pandemic and self-isolation, one can note that there is no emotionally pronounced mood. After analyzing the responses of informants, one can note that the main idea of the media video, without exception (100\%), is that "we need to be treated on time and self-isolate" (male, 47 years old)

More than half of the participants note that the information in the advertisement does not cause them trust (51\%) "The information does not cause trust because I cannot believe that there are so many victims" 
Tatyana A. Olkhovaya, Elena A. Sorokoumova, Nikolai A. Mashkin, Tatyana S. Vinogradova,

Jhanna I. Aytuganova, Igor V. Romanov, Evgeniya V. Gots y Irina R. Pozdnyakova

80

Media clips on social fear to regulate individual behavior in temporary involuntary isolation

(quarantine)

(female, 52 years), a smaller part (49\%) think that the advertisement is useful and can be trusted "well, maybe the coronavirus is not as dangerous as it is said, but I still believe" (female, 55 years); "I trust the information" (male, 55 years). All respondents (100\%) found social advertising about the coronavirus pandemic and self-isolation useful. This is evidenced by the following opinions: "I liked the advertisement» (male, 36 years old).

Emotions caused by watching this video are fear, frustration, regret, and pity. Almost all participants (97\%) believe that the main idea of the videos is to draw the audience's attention to their health and the health of older people. "Every person is very vulnerable, and it is impossible to guess what is waiting for them and where" (female, 52 years old). Most of the participants in the discussion (63\%) are skeptical about social videos about the coronavirus pandemic and self-isolation, and believe that self-isolation cannot guarantee complete isolation from the coronavirus "I'm not sure that self-isolation will help much" (male, 36 years old).

After analyzing the responses of viewers of media social videos, we came to the conclusion that to a greater extent, participants experienced negative emotions (81\%), but also positive emotions occur "sharply negative, incomprehensible and unpleasant, most likely it is more like a big question mark in my head. Causes pessimism, because is everything so bad in our life" (male, 49 years old). Participants note that this advertisement causes them trust "Causes trust because it shows that the problem of the coronavirus pandemic" (female, 38 years old), and several people say that the advertisement does not cause trust "It does not cause trust, because anything can really happen, and sometimes no self-isolation will save. But as a means of security, of course, you must use it " (female, 54 years old) Participants (97\%) emphasize that using an emotion such as fear makes them pay attention to the social situation, thus making it more meaningful. Most middle-aged people (83\%) experience more fear (apprehension) after watching social videos.

\section{Conclusions}

Social fear is, first, a mechanism of subordination to the crowd or its individual leaders. Fear as a social phenomenon has a mass, collective, conscious, coordinated, and rational character. In General, based on the results of the discussion, we can note a number of key points that allow us to conclude that the reasonable use of fear emotions in social videos dedicated to the coronavirus pandemic and self-isolation as a mechanism for regulating the behavior of viewers of media social videos is not only acceptable, but also productive. First, an advertisement that involves the emotion of fear attracts the attention of potential viewers, because it seems 
to them creative, unusual, and not similar to similar advertisements.

Second, such media videos force people to fix their attention on possible problems, suggesting ways to solve them. Third, the emotion of fear in media videos makes consumers think about the impact of external factors on their daily life, thereby motivating them to think through their further actions in such a way as to avoid possible unnecessary consequences. In addition, fourthly, the thoughtful use of the emotion of fear in media social videos really contributes to changing the behavior of potential viewers during the coronavirus pandemic.

However, we would like to note that the use of the emotion of fear in media activity is fraught with not only pros, but also cons. As many informants note it, the frequent display of some advertisements should be banned altogether. The fear depicted in them can harm the mental health of people with weak nervous systems, the elderly, and children. At the same time, the use of fear emotion in media social videos as a mechanism for regulating individual behavior is not only acceptable, but also productive for such reasons as: social videos that involve the emotion of fear attract attention; such social videos make people focus their attention on possible problems, offering ways to solve them; social advertising with the use of fear emotion acts as a motive that encourages certain behavior.

The disadvantages of using the emotion of fear in social videos include the problem of ethics and content of social advertising (if the created social videos undermine the ability of the individual to make rational and free choices, or exploit human weaknesses). High-quality media videos are more popular than those whose story is unclear and tasteless. Fear associated with non - compliance with certain values and norms accepted in society is the most exploited in social videos dedicated to self-isolation.

\section{Bibliographic References}

ADLER, Alfred. 1997. Understand the nature of man. Academic project. Saint Petersburg, Russia.

CHERDYMOVA, Elena I. 2017. "Possibilities of art therapy for the development of emotional intelligence of elderly people for the purpose of health saving" In: Bulletin of the Shadrinsk state pedagogical University, No. 2, pp. 68-72.

CHERDYMOVA, Elena I; ILKEVICH, Tatyana G; SPIRINA, Elena V; BLINOV, Leonid V; ALIYEV, Hibi K; KUKHTYAEVA, Elena A; IVANSHINA, Irina A. 2019. "Physicality ecology: student attitude to their own body" In: Ekoloji. Vol. 28, No. 107, pp. 4925-4930. 
Tatyana A. Olkhovaya, Elena A. Sorokoumova, Nikolai A. Mashkin, Tatyana S. Vinogradova, Jhanna I. Aytuganova, Igor V. Romanov, Evgeniya V. Gots y Irina R. Pozdnyakova

DODONOV, Boris Ignatevič. 1987. In the world of emotions. Politizdat. Kiev, Ukraine.

EKMAN, Paul. 2010. Psychology of emotions. I know how you feel. Peter Press. Saint Petersburg, Russia.

FREUD, Sigmund. 1997. Introduction to psychoanalysis. Nauka. Moscow, Russia.

GUDKOV, Lev. 1999. "Fear as a framework for understanding what is happening" In: Public opinion monitoring. No. 6, pp. 46-53.

HEGEL, Georg Vilhelm Fridrih. 1977. Encyclopedia of philosophical Sciences. Mysl. Moscow, Russia.

HEIDEGGER, Martin. 1994. Time and being: Articles and speeches. Republic. Moscow, Russia.

HORNEY, Karen. 1982. Culture and neurosis. Psychology of personality. MSU Publishing house. Moscow, Russia.

IVANTSOVA, Dmitry A. 2003. How to get rid of fears and start enjoying life in a week. IK “Nevsky Prospekt”. Saint Petersburg, Russia.

IZARD, Carroll E. 1999. Psychology of emotions. Peter. Saint Petersburg, Russia.

JASPERS, Karl. 1991. The Meaning and purpose of history. Politizdat. Moscow, Russia.

KANBUL, Sezer; KALLAGOV, Taymuraz E; RUBANIK, Vladimir E; KHAIRULLINA, Elmira R; RIBAKOVA, Laysan A. 2019. "Determination of Mobile Addiction and Social Media Addiction Level of Parents and Their Attitudes towards Usage of Technology" In: International Journal of Emerging Technologies in Learning. Vol. 14 No. 22, 175-191.

KEPALAITE, Albina; SUVOROVA, Alla V. 1991. "Experimental study of positive and negative emotions" In: Questions of psychology. No. 2, pp. 140 - 147.

KHAIRULLINA, Elmira R; MAKHOTKINA, Liliya Yu; SVETLAKOV, Anatoly P; EMELINA, Ellina D; VYATKINA, Irina V; LIPATOVA, Irina A; PAVLUSHIN, Andrey A; SOROKOUMOVA, Elena A. 2019. "Noosphere Concept Implementation in Methodology of Modern Ecologically Oriented Higher Education: Theoretical Aspect” In: Ekoloji. Vol. 28 No. 107, 713-720.

KONOPKIN, Oleg Aleksandrovic. 2006. "Participation of emotions in the conscious regulation of directed human activity" In: Voprosy psikhologii. No. 43, pp. 38-48. 
KOSTANDOV, Èduard Arutûnovič. 1977. Perception and emotions. Medicine. Moscow, Russia.

LEONTIEV, Aleksei Nikolaevitch. 1984. Motivational theory of emotions. Psychology of emotions. MSU. Moscow, Russia.

MELNICHUK, Marina V; OSIPOVA, Valentina M. 2017. "Cooperative learning as a valuable approach to teaching translation” In: Xlinguae. Vol. 10 No. 1, pp. 25-33.

MISHIN, Gennadity I. 1984. Negative emotions and their overcoming. Meditsina. Moscow, Russia.

NIETZSCHE, Friedrich. 1990. The Anti-Christian. Twilight of the gods. Politizdat. Moscow, Russia.

OIZERMAN, Teodor Il'ich. 1974. Kant's Philosophy and our modernity. Mysl. Moscow, Russia.

OLKHOVAYA, Tatyana A; MERCULOVA, Lyudmila V; CHERDYMOVA, Elena I; SUKHODOLOVA, Evgenia M; MANAKOVA, Olga S; LAPTEV, Alexey A. \& Popova, Olga V. 2019. "The biomedical research on peculiarities of student's communicative skills development" In: International Journal of Advanced Biotechnology and Research. No. 10, pp. 101-110.

PUTILINA, Elena S; CHERDYMOVA, Elena I; KURBANOV, Rashad A; BELYALOVA, Asiya M; SHATSKAYA, Irina I; KOBZEVA, Ekaterina I; ZHURAVLEVA, Marina V; \& MELESHKO, Georgy S. 2019. "Ecological relationships in real and virtual environments: contact points" In: EurAsian Journal of BioSciences Eurasia J Biosci. No. 13, pp. 1475-1480.

REIKOVSKY, Ya. 1979. Experimental psychology of emotions. Progress. Moscow, Russia.

RUBINSTEIN, Sergey L. 1973. Problems of General psychology. Pedagogy. Moscow, Russia.

SCHOPENHAUER, Arthur. 1971. The World as willness and presentation. Anthology of world J philosophy. Bourgeois philosophy of the end of the XVIII century, the first two-thirds of the XIX century. Mysl. Moscow, Russia.

SHINGAROV, Georgiĭ Khristovich. 1971. Emotions and feelings as a factor of reflection of reality. Nauka. Moscow, Russia.

SOROKOUMOVA, Elena A. 2009. "Self-knowledge in the process of enriching consciousness. Bulletin of the Moscow state University for the Humanities named after M.A” In: Sholokhov. No. 3, pp. 89-94. 
Tatyana A. Olkhovaya, Elena A. Sorokoumova, Nikolai A. Mashkin, Tatyana S. Vinogradova, Jhanna I. Aytuganova, Igor V. Romanov, Evgeniya V. Gots y Irina R. Pozdnyakova Media clips on social fear to regulate individual behavior in temporary involuntary isolation

SOROKOUMOVA, Elena A; CHERDYMOVA, Elena I; REZVANTSEVA, Marina O; KOCHNEVA, Lyubov V; LATYSHEVA, Valentina V; \& PERKOVA, Ekaterina P. 2019. "Environmental and Social Practices of Old Stuff Use and Disposal by Students” In: Ekoloji. Vol. 28 No. 107, pp. 5065-5069.

STEVENE, Joshua. 1996. Tame your dragons. Peter Press. Saint Petersburg, Russia.

USAK, Muhammet; MASALIMOVA, Alfiya R; CHERDYMOVA, Elena I; SHAIDULLINA, Albina R. 2020. "New playmaker in science education: Covid-19" In: Journal of Baltic Science Education. Vol. 19 No. 2, pp. 180185 .

VASBIEVA, Dinara G; SOKOLOVA, Nataliya L; MASALIMOVA, Alfiya R; SHINKARUK, Vladimir M; Kiva-KHAMZINA, Yuliya Leonidovna. 2018. "Exploring the EFL teacher's role in a smart learning environment - a review study" In: Xlinguae. Vol. 11 No. 2, pp. 265-274.

VILYUNAS, Vitis K. 1976. Psychology of emotional phenomena. Moek Publishing house, University. Moscow, Russia.

VILYUNAS, Vitis K. 2004. Psychology of emotions. Peter Press. Saint Petersburg, Russia.

WUNDT, Wilhelm. 1913. Elements of peoples' psychology. The main features of the psychological history of human development. Bitner. Saint Petersburg, Russia.

ZAKHAROV, Anatoly I. 1995. How to help our children get rid of fear? Nauka. Saint Petersburg, Russia. 


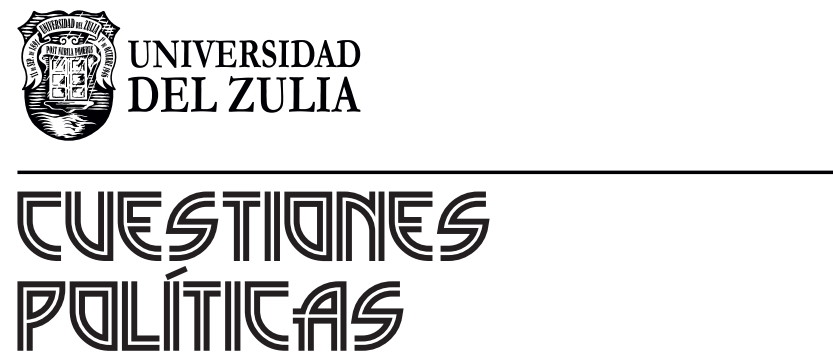

Vol.38 NEspecial

Esta revista fue editada en formato digital y publicada en octubre de 2020, por el Fondo Editorial Serbiluz, Universidad del Zulia. Maracaibo-Venezuela 